\title{
ITGAD wt Allele
}

National Cancer Institute

\section{Source}

National Cancer Institute. IT GAD wt Allele. NCI Thesaurus. Code C120291.

Human IT GAD wild-type allele is located in the vicinity of 16 p11.2 and is approximately 33 $\mathrm{kb}$ in length. This allele, which encodes integrin alpha-D protein, is involved in both cell-cell and cell-extracellular matrix interactions and cell communication. 